\title{
Analisis Kesalahan Siswa Dalam Menyelesaikan Soal Matematika Berbasis HOTS Materi Pola Bilangan Berdasarkan Kriteria Hadar
}

\author{
St. Nur Humairah Halim ${ }^{*}$, Sitti Rahmah Tahir ${ }^{1}$, Andi Alim \\ Syahri $^{1}$, Husriana ${ }^{2}$
}

1 Pendidikan Matematika, FKIP, Universitas Muhammadiyah Makassar, Makassar
2 Mahasiswa Pendidikan Matematika, FKIP, Universitas Muhammadiyah Makassar, Makassar

humairah@unismuh.ac.id

\begin{abstract}
This study aims to determine the types of errors made by class VIII students of SMP Satap 3 Tellu Limpoe, Bone Regency, in solving mathematics problems based on Higher Order Thinking Skills on number pattern material based on Hadar criteria. The subjects in this study were class VIII SMP Satap 3 Tellu Limpoe, Bone Regency, which amounted to 14 people, then 2 students were selected as research subjects to be interviewed, namely students who made the most mistakes based on the Hadar error criteria indicator. The research instrument was used in the form of a HOTS-based math test for number patterns and interview guidelines. While the data were analyzed using qualitative descriptive analysis and continued with triangulation techniques to test the validity of the data. The results obtained are the types of errors made by class VIII students of SMP Satap 3 Tellu Limpoe, Bone Regency in solving mathematics problems based on Higher Order Thinking Skills on number pattern material based on Hadar criteria, including (1) errors in using data, (2) errors in interpreting language, (3) errors using logic when concluding, (4) errors using definitions or theorems, and (5) the solution is not checked again.
\end{abstract}

Keywords: error Analysis; HOTS questions; Hadar criteria; number pattern

\begin{abstract}
Abstrak
Penelitian bertujuan untuk mengetahui jenis kesalahan yang dilakukan siswa kelas VIII SMP Satap 3 Tellu Limpoe Kabupaten Bone dalam menyelesaikan soal matematika berbasis Higher Order Thinking Skills pada materi pola bilangan berdasarkan kriteria Hadar. Subjek dalam penelitian ini adalah kelas VIII SMP Satap 3 Tellu Limpoe Kabupaten Bone yang berjumlah 14 orang kemudian dipilih subjek penelitian sebanyak 2 orang siswa untuk diwawancarai yaitu siswa yang melakukan kesalahan terbanyak berdasarkan indikator kriteria kesalahan Hadar. Adapun Instrumen penelitian yang digunakan berupa tes soal matematika berbasis HOTS materi pola bilangan dan pedoman wawancara. Sedangkan data dianalisis dengan menggunakan analisis deksriptif kualitatif dan dilanjutkan dengan triangulasi teknik untuk menguji keabsahan data. Hasil penelitian yang diperoleh adalah jenis kesalahan yang dilakukan siswa kelas VIII SMP Satap 3 Tellu Limpoe Kabupaten Bone dalam menyelesaikan soal matematika berbasis Higher Order Thinking Skills pada materi pola bilangan berdasarkan kriteria Hadar adalah antara lain (1) kesalahan menggunakan data, (2) kesalahan menginterpretasi bahasa, (3) kesalahan menggunakan logika ketika menarik kesimpulan, (4) kesalahan menggunakan definisi ataupun teorema, dan (5) penyelesaiannya tidak diperiksa kembali.
\end{abstract}

Kata Kunci: analisis kesalahan; soal HOTS; kriteria Hadar; pola bilangan 


\section{PENDAHULUAN}

Implementasi Kurikulum 2013 dalam proses pembelajaran matematika merupakan pelaksanaan program kurikulum ke dalam praktik pembelajaran matematika, sehingga terjadi perubahan dalam diri peserta didik baik perubahan pengetahuan, keterampilan maupun sikap. Implementasi Kurikulum 2013 dalam proses pembelajaran terdiri dari tiga tahap yaitu tahap perencanaan, tahap pelaksanaan, dan tahap penilaian. Dalam pelaksanakan Kurikulum 2013 guru harus dapat memahami konsep dasar kurikulum dan kemampuan merencanakan Kurikulum 2013 yaitu penyusunan Rencana Pelaksanaan Pembelajaran (RPP), pelaksanakan pembelajaran berbasis Kurikulum 2013 serta mampu melaksanakan penilaian (Kusnadi et al., 2014). Hal ini menunjukkan bahwa langkah utama yang menjadi dasar untuk mengimplementasikan kurikulum 2013 adalah penyusunan RPP itu sendiri dan bagaimana mengimplementasikannya.

Salah satu aspek RPP yang diharapkan dapat mengimplementasikan kurikulum 2013 adalah RPP yang mampu mengakomodasi pengembangan kemampuan berpikir tingkat tinggi (Ratumanan \& Tetelepta, 2019). Kemampuan berpikir tingkat tinggi ini selanjutnya lebih dikenal dengan istilah HOTS (High Order Thinking Skill). Hal inilah yang menjadi momok bagi guru untuk menerapkan RPP yang berbasis HOTS ini, karena diperlukan kreativitas dan kompetensi yang mumpuni demi mengembangkan skill siswa ke tahap bernalar yang mampu menganalisis, mengevaluasi, dan mencipta (Purbaningrum, 2017; Rasyidi \& Winarso, 2020).

Kenyataan juga menunjukkan bahwa tidak hanya guru yang kesulitan dengan perubahan kurikulum yang menuntut adanya HOTS ini, tetapi hasil belajar siswa yang menjadi output dari proses pembelajaran berbasis HOTS ini masih jauh dari yang diharapkan. Seperti yang terlihat pada ranking siswa Indonesia pada PISA dan TIMSS, yang merupakan tes skala internasional yang juga mencakup aspek HOTS, tercatat pada tahun 2015 Indonesia menduduki peringkat ke-64 dari 72 negara yang berpatisipasi pada PISA, dan menduduki peringkat ke-45 dari 48 negara yang berpatisipasi pada TIMSS (Amalia \& Pujiastuti, 2020; Manik et al., 2020).

Rendahnya hasil yang diperoleh siswa saat mengerjakan soal yang berbasis HOTS tentu saja dipengaruhi akan seberapa banyak kesalahan yang dilakukan siswa tersebut. Kesalahan-kesalahan siswa perlu dianalisis untuk mengetahui variasi kesalahan yang dilakukan oleh siswa. Melalui analisis kesalahan akan diperoleh jenis dan letak kesalahan yang dilakukan siswa, sehingga guru dapat memberikan jenis bantuan yang tepat kepada siswa (Gusman et al., 2021; Kepa \& Ramli, 2021; Schnepper et al., 2014).

Hal ini pula yang peneliti temukan saat melakukan wawancara dengan guru matematika SMP Satap 3 Tellu Limpoe Kabupaten Bone pada tanggal 26 Juni 2020, peneliti mengidentifikasi bahwa masih banyak siswa melakukan kesalahan dalam menyelesaikan soal matematika yang berhubungan dengan menganalisis, mengevaluasi, dan mencipta. Kesalahan yang biasa dilakukan pada saat siswa mengerjakan soal matematika berbasis HOTS pada materi pola bilangan yaitu: 1) Kesalahan menggunakan 
data yaitu kesalahan yang terjadi karena siswa menyalin data dari soal kurang tepat dan siswa biasa mengabaikan data yang diberikan; 2) Kesalahan menginterpretasi bahasa seperti kesalahan siswa mengubah soal cerita menjadi persamaan matematika dengan makna yang beda; 3) Kesalahan menggunakan definisi ataupun rumus seperti dalam menyelesaikan soal siswa menggunakan rumus barisan geometri padahal rumus yang dibutuhkan untuk menyelesaikan soal tersebut adalah deret geometri; 4) Penyelesaian tidak diperiksa kembali yaitu kesalahan yang terjadi karena siswa menyelesaikan soal dengan buru-buru sehingga jawabannya tidak diperiksa kembali sehingga hasil akhir dan langkah penyelesaiannya tidak sama; 5) Kesalahan teknis seperti kesalahan yang terjadi karena kesalahan perhitungan.

Hal tersebut sejalan dengan hasil penelitian terdahulu bahwa subjek yang menyelesaikan soal HOTS pada materi aljabar membuat kesalahan saat mengartikan bahasa, membuat kesalahan saat penggunaan logika untuk membuat kesimpulan, serta kesalahan penggunaan definisi ataupun rumus sedangkan kesalahan ketika memecahkan masalah matematika HOTS materi geometri kebanyakan terjadi kesalahan dalam penggunaan logika ketika membuat kesimpulan, kesalahan dalam penggunaan definisi ataupun rumus, serta kesalahan teknis (Laman, 2019).

Adapun klasifikasi jenis kesalahan menurut Hadar yaitu kesalahan data, kesalahan menginterpretasikan bahasa, kesalahan menggunakan logika untuk menarik kesimpulan, kesalahan menggunakan definisi atau teorema, penyelesaian tidak diperiksa kembali dan kesalahan teknis (Anwar \& Hidayani, 2020; Gina et al., 2021).

Kesalahan siswa ketika menjawab suatu soal dapat dianalisis dengan melihat jawaban siswa saat menjawab soal, sehingga dapat diketahui jenis kesalahan yang dilakukan siswa saat mengerjakan soal matematika. Menganalisis jawaban siswa menggunakan kriteria kesalahan menurut Hadar merupakan salah satu cara untuk menganalisis jenis kesalahan yang dilakukan siswa pada saat menyelesaikan soal matematika berbasis HOTS.

Berdasarkan pemaparan diatas sehingga peneliti tertarik untuk meneliti tentang "Analisis Kesalahan Siswa Dalam Menyelesaikan Soal Matematika Berbasis Higher Order Thinking Skills (HOTS) Materi Pola Bilangan Berdasarkan Kriteria Hadar".

\section{METODE PENELITIAN}

Penelitian ini dilaksanakan di SMP Satap 3 Tellu Limpoe Kabupaten Bone. Waktu penelitian yaitu tanggal 20 September - 15 Oktober 2020. Subjek dalam penelitian ini adalah kelas VIII SMP Satap 3 Tellu Limpoe Kabupaten Bone berjumlah 14 siswa. Sedangkan subjek penelitian ini ditetapkan sebanyak 2 orang siswa untuk diwawancarai yaitu siswa yang melakukan kesalahan terbanyak berdasarkan indikator kriteria kesalahan Hadar. Adapun jika jumlah kesalahan antar subjek sama maka dipilih subjek yang bersedia mengikuti semua proses dalam penelitian ini serta peneliti membandingkan semua jenis kesalahan yang dilakukan subjek. 
Tahapan dalam penelitian ini antara lain:

a. Tahap persiapan

i. Observasi di SMP Satap 3 Tellu Limpoe Kabupaten Bone.

ii. Merancang instrumen penelitian.

b. Tahap pelaksanaan

i. Memberi soal matematika berbasis HOTS

ii. Menganalisis kesalahan siswa saat menyelesaikan soal matematika berbasis HOTS menggunakan kriteria Hadar.

iii. Memilih 2 subjek yang melakukan kesalahan terbanyak berdasarkan indikator kriteria kesalahan Hadar untuk diwawancarai.

iv. Melakukan wawancara.

v. Menyimpulkan jenis kesalahan siswa dari hasil tes serta wawancara.

Instrumen yang digunakan pada penelitian ini berupa tes soal matematika berbasis HOTS sebanyak 5 soal materi pola bilangan dengan alokasi waktu 80 menit. Setelah siswa menyelesaikan soal tersebut, jawaban siswa lalu dianalisis kesalahannya menggunakan kriteria Hadar. Teknik pengumpulan data yang dilakukan pada penelitian ini yaitu :

a. Tes soal matematika berbasis HOTS

Tes dikerjakan oleh siswa untuk memperoleh data tentang kesalahan siswa ketika menyelesaikan soal. Dari hasil tes tersebut didapat kesalahan siswa saat mengerjakan suatu soal, dan dianalisis menggunakan kriteria Hadar untuk mendapatkan kesalahan apa yang dilakukan siswa saat menyelesaikan soal HOTS pada materi pola bilangan berdasarkan kriteria Hadar.

b. Wawancara

Setelah memeriksa jawaban siswa saat menyelesaikan soal matematika berbasis HOTS pada materi pola bilangan dilakukan wawancara. Jenis wawancara yang digunakan dalam penelitian ini adalah wawancara tak terstruktur yaitu peneliti mengajukan pertanyaan kepada subjek terkait dengan poin penting yang mau diketahui dari lembar jawaban subjek tanpa menggunakan pedoman wawancara yang biasanya berisikan pertanyaan. Tujuan untuk wawancara adalah digunakan sebagai cara mendapatkan data secara lengkap serta rinci mengenai jenis kesalahan yang dilakukan siswa saat menyelesaikan soal matematika berbasis HOTS pada materi pola bilangan berdasarkan kriteria Hadar.

Teknik analisis data yang dilakukan dengan tahapan: 1) Reduksi data dilakukan dengan merujuk pada proses pemilihan data mentah yang diperoleh dari catatan lapangan. 2) Penyajian data dalam bentuk teks naratif atau teks yang bersifat narasi. 3) penarikan kesimpulan dengan melakukan penarikan kesimpulan terhadap hasil penelitian yang diperoleh di lapangan.

Untuk mendapatkan data yang valid, maka peneliti menggunakan triangulasi yaitu teknik pemeriksaan kebenaran atau keabsahan data yang dilakukan 
dengan cara membandingkan atau menggabungkan data-data yang telah terkumpulkan sehingga diperoleh data yang benar-benar autentik dan objektif. Adapun teknik triangulasi yang digunakan pada penelitian ini yaitu triangulasi metode, yakni teknik triangulasi yang dilakukan dengan membandingkan dan menggabungkan data hasil tes tertulis dan wawancara terhadap subjek penelitian.

\section{HASIL DAN PEMBAHASAN}

\subsection{Hasil Penelitian}

Berikut analisis deskriptif mengenai jenis kesalahan yang dilakukan 2 subjek penelitian yang terpilih dalam menyelesaikan soal matematika berbasis HOTS pada materi pola bilangan berdasarkan kriteria Hadar:

a. Subjek 1

Kesalahan yang dilakukan subjek 1 dalam menyelesaikan soal matematika berbasis HOTS materi pola bilangan ada pada soal nomor 1,2,3, dan 4 adalah sebagai berikut:

i. Soal nomor 1

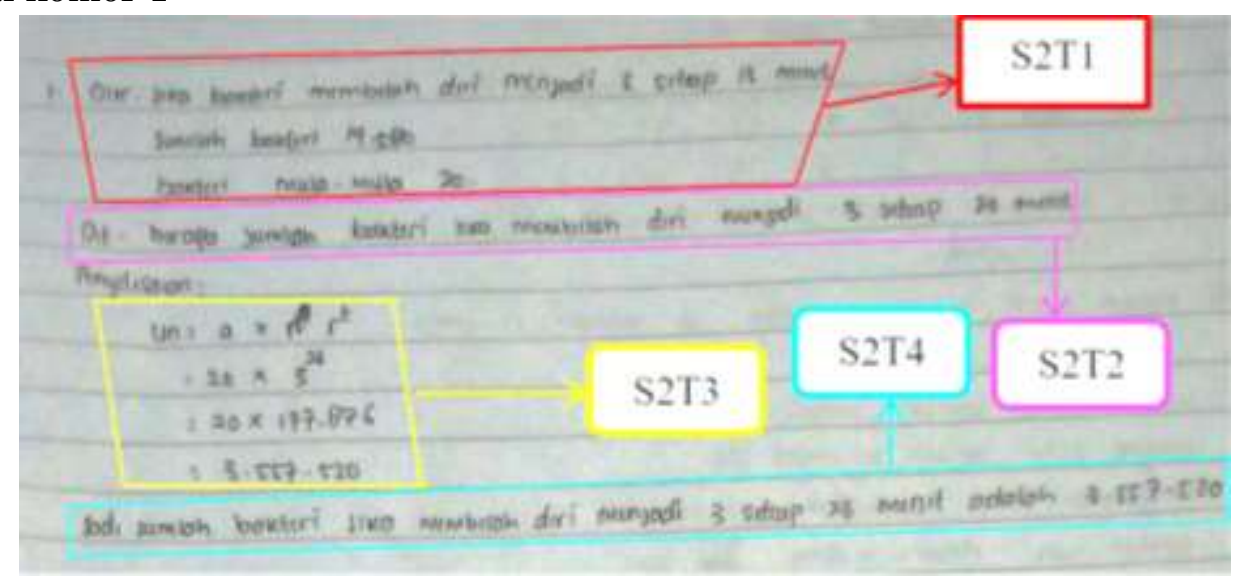

Gambar 1. Lembar jawaban subjek 1 soal nomor 1

Gambaran data untuk setiap kesalahan yang dilakukan subjek 1 pada soal nomor 1 dijelaskan sebagai berikut:

1) Kesalahan menggunakaan data

Berdasarkan lembar jawaban subjek pada Gambar 1 dan hasil wawancara terlihat bahwa subjek mengabaikan sebagian data yang diberikan yaitu subjek hanya menggunakan data bakteri mula-mula dan jika bakteri membelah diri menjadi 3 setiap 26 menit (S2T1, S2T2, S2T3). Subjek mengartikan informasi pada soal tidak sesuai dengan teks sebenarnya sehingga subjek mengabaikan sebagian data dalam menyelesaikan soal yaitu subjek mengabaikan data jika jumlah bakteri membelah diri menjadi tiga setiap 13 menit, dan subjek tidak mencari waktu t yang dibutuhkan sehingga jumlah bakteri menjadi 14.580 .

2) Kesalahan menginterpretasi bahasa

Berdasarkan lembar jawaban subjek pada Gambar 1 dan hasil wawancara terlihat bahwa subjek keliru dalam menafsirkan kalimat soal diperlukan 
waktu t agar jumlah bakteri menjadi 14.580, subjek manganggap bahwa waktunya itu adalah ketika bakteri membelah diri menjadi 3 setiap 13 menit. Sehingga subjek menganggap yang ditanyakan pada soal yaitu banyak bakteri ketika membelah diri menjadi 3 setiap 26 menit padahal yang ditanyakan adalah banyak bakteri ketika membelah diri menjadi 3 setiap 26 menit setelah waktu t (S2T1, S2T2).

3) Kesalahan menggunakan logika untuk menarik kesimpulan

Berdasarkan lembar jawaban subjek pada Gambar 1 dan hasil wawancara terlihat bahwa subjek keliru dalam mengambil kesimpulan dengan menentukan bahwa ketika jumlah bakteri menjadi 14.580 waktunya hanya 13 menit, dan subjek keliru menentukan jumlah bakteri ketika membelah diri menjadi 3 setiap 26 menit, sebaiknya subjek menentukan berapa waktu yang di butuhkan sehingga jumlah bakteri menjadi 14.580 ketika bakteri membelah diri menjadi 3 setiap 13 menit sebelum menentukan jumlah bakteri setelah waktu t ketika membelah diri menjadi 3 setiap 26 menit (S2T1, S2T2, S2T3).

4) Kesalahan menggunakan definisi atau teorema

Berdasarkan lembar jawaban subjek pada Gambar 1 dan wawancara terlihat bahwa subjek terlihat telah menuliskan rumus yang dibutuhkan untuk menyelesaikan soal yaitu $U_{n}=a x r^{t}$ tetapi subjek tidak menerapkan rumus yang tepat untuk menyelesaikan soal (S2T3).

ii. Soal nomor 2

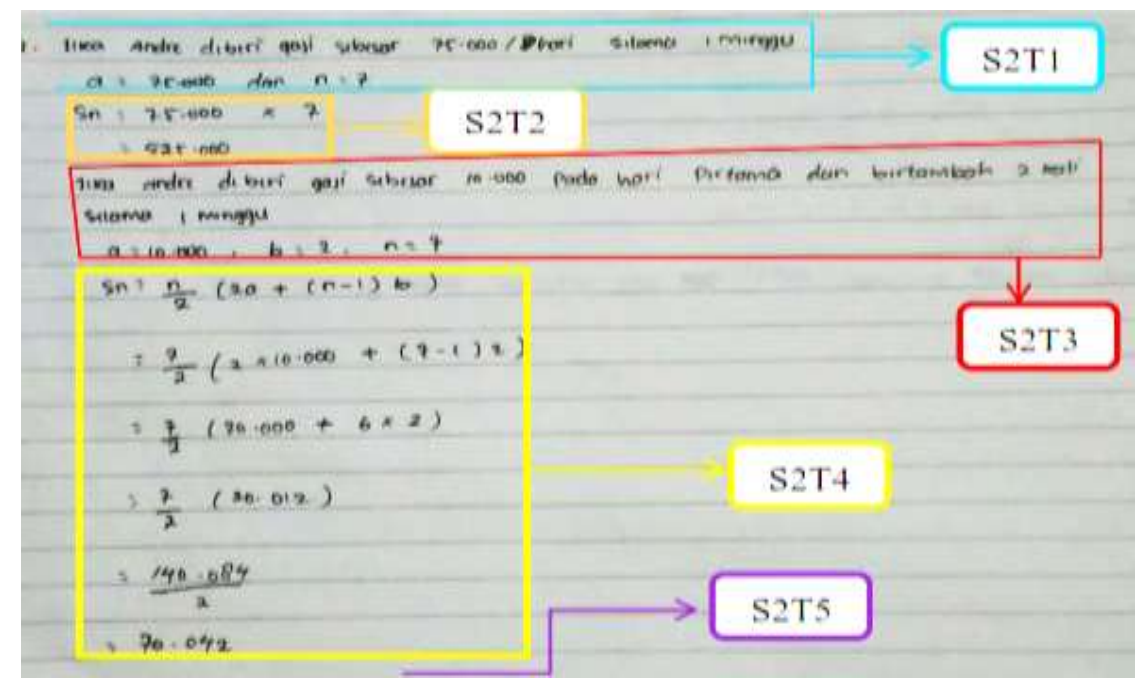

Gambar 2. Jawaban subjek 1 soal nomor 2

Gambaran data untuk setiap kesalahan yang dilakukan subjek 1 pada soal nomor 2 dijelaskan sebagai berikut:

1) Kesalahan menggunakan data

Berdasarkan lembar jawaban subjek pada gambar 2 dan wawacara terlihat bahwa subjek mengartikan infomasi pada soal tidak sesuai dengan teks sebenarnya yaitu subjek menganggap bahwa pada gaji yang diberikan pada pilihan kedua andre yaitu Rp10.000 pada hari pertama dan hanya 
akan bertambah 2 setiap harinya padahal informasi pada soal gaji andre akan bertambah 2 kali lipat tiap harinya selama seminggu (S2T3).

2) Kesalahan menginterpretasi bahasa

Berdasarkan lembar jawaban subjek pada gambar 2 dan wawancara terlihat bahwa subjek keliru dalam menafsirkan gaji sebesar Rp10.000 pada hari pertama dan bertambah 2 kali lipat tiap harinya, subjek menganggap bahwa gaji andre hanya bertambah 2 setiap harinya sehingga subjek salah dalam membuat model matematikanya yaitu $b=2$ padahal yang diketahui pada soal adalah $\mathrm{r}=2$ (S2T3).

3) Kesalahan menggunakan logika untuk menarik kesimpulan

Berdasarkan lembar jawaban subjek pada gambar 2 dan wawancara terlihat bahwa subjek keliru dalam mengambil kesimpulan dengan menentukan bahwa ketika andre di beri gaji Rp 10.000 pada hari pertama dan bertambah dua kali lipat tiap harinya selama seminggu subjek langsung menarik kesimpulan bahwa gaji andre hanya akan bertambah 2 tiap harinya selama seminggu sehingga subjek menarik kesimpulan bahwa soal tersebut merupakan deret aritmatika padahal soal tersebut adalah deret geometri (S2T3, S2T4).

4) Kesalahan menggunakan definisi atau teorema

Berdasarkan lembar jawaban subjek pada gambar 2 dan wawancara terlihat bahwa subjek telah menuliskan rumus yang dibutuhkan dalam menyelesaikan soal yaitu pilihan pertama $\mathrm{Sn}=\mathrm{a} \times \mathrm{n}$ dan pilihan kedua $S_{n}=\frac{n}{2}(2 a+(n-1) b)$. Tetapi subjek keliru dalam menentukan rumus yang digunakan untuk pilihan kedua. Rumus yang dituliskan yaitu rumus deret aritmatika padahal rumus yang dibutuhkan untuk penyelesaian soal tersebut adalah deret geometri yaitu $S_{n}=\frac{a\left(r^{n}-1\right)}{r-1}$ (S2T4).

5) Penyelesaian tidak diperiksa kembali

Berdasarkan lembar jawaban subjek pada gambar 2 dan wawancara terlihat bahwa subjek terlihat tidak menuliskan kesimpulan dari langkah penyelesaiannya (S2T5).

iii. Soal nomor 3 


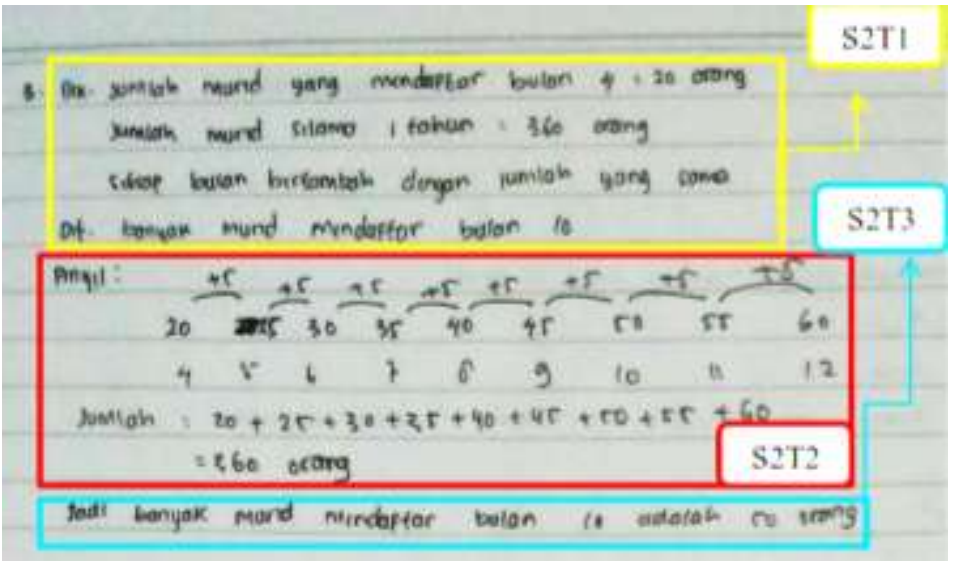

Gambar 3. Jawaban subjek 1 soal nomor 3

Gambaran data untuk setiap kesalahan yang dilakukan subjek 1 pada soal nomor 3 dijelaskan sebagai berikut:

1) Kesalahan menginterpretasi bahasa

Berdasarkan lembar jawaban subjek pada gambar 3 dan wawancara terlihat bahwa subjek keliru dalam menafsirkan informasi pada soal yaitu subjek menganggap bahwa pendaftaran murid baru di mulai dari bulan 4 sehingga subjek menetukan suku pertamanya yaitu bulan ke 4 (S2T1, S2T2).

2) Kesalahan menggunakan logika untuk menarik kesimpulan

Berdasarkan lembar jawaban subjek pada gambar 3 dan wawancara terlihat bahwa subjek keliru dalam mengambil kesimpulan dengan menentukan bahwa suku pertama pola tersebut adalah pada bulan ke 4 yaitu 20 seharusnya subjek mencari jumlah murid yang mendaftar pada bulan 1, 2 dan 3 yaitu $\mathrm{U}_{1}, \mathrm{U}_{2}$, dan $\mathrm{U}_{3}$ sebelum menentukan jumlah murid yang mendaftar bulan 10 karena jumlah murid baru yang mendaftar selama 1 tahun pertama adalah 360 orang berarti pendaftaran murid baru mulai dari bulan 1 sampai bulan 12 (S2T2).

iv. Soal nomor 4

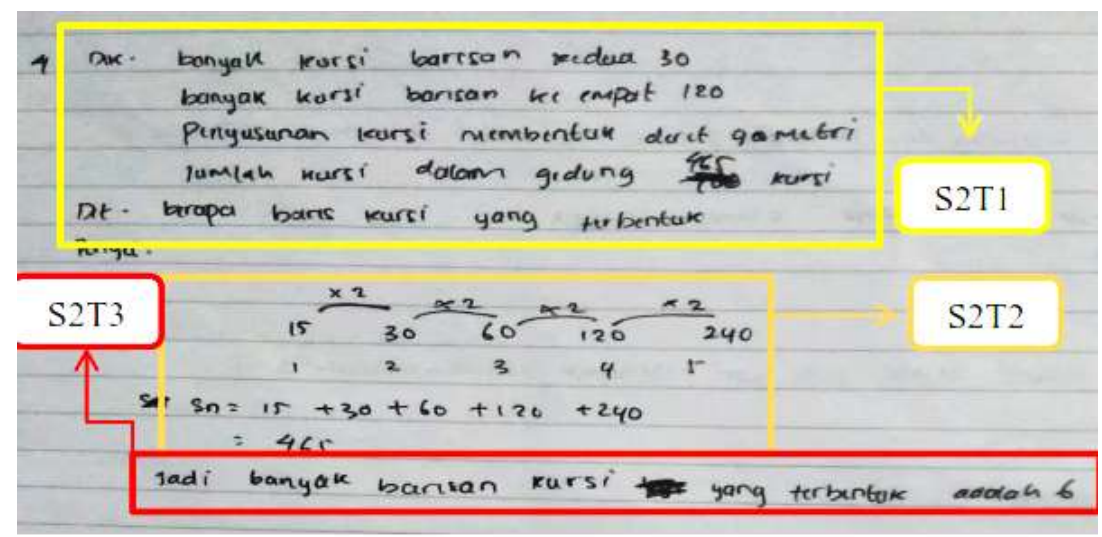

Gambar 4. Jawaban subjek 1 soal nomor 4

Berdasarkan lembar jawaban subjek pada gambar 4 dan wawancara terlihat bahwa subjek jawaban akhir subjek tidak sesuai dengan langkah 
penyelesaiannya. Subjek menuliskan jawaban akhirnya yaitu banyak kursi yang terbentuk adalah 6 baris padahal subjek telah mendapatkan hasilnya yaitu 5 baris (S2T2, S2T3).

b. Subjek 2

Kesalahan yang dilakukan subjek 2 dalam menyelesaikan soal matematika berbasis HOTS materi pola bilangan ada pada soal nomor 2,3, dan 4 adalah sebagai berikut:

i. Soal nomor 2

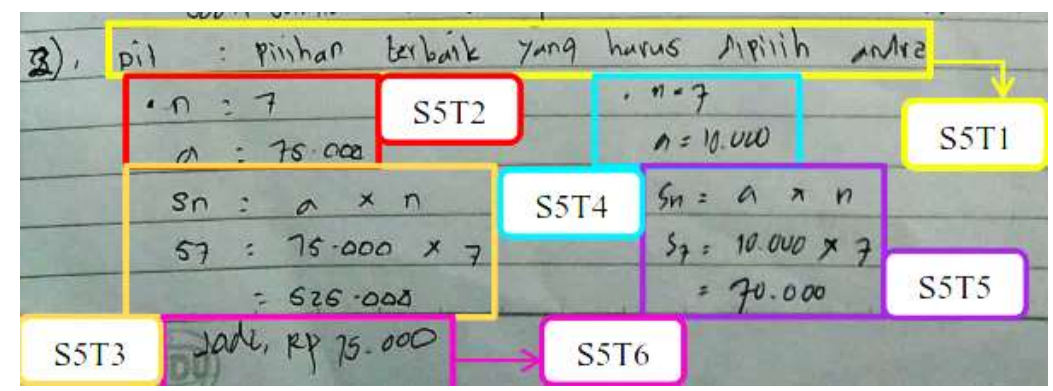

Gambar 5. Jawaban subjek 2 soal nomor 2

Gambaran data untuk setiap kesalahan yang dilakukan subjek 2 pada soal nomor 2 dijelaskan sebagai berikut:

1) Kesalahan menggunakan data

Berdasarkan lembar jawaban subjek pada gambar 5 dan wawancara terlihat bahwa subjek mengabaikan sebagian data yang ada dalam soal pada pilihan kedua andre yaitu subjek mengabaikan data gaji andre bertambah 2 kali lipat tiap harinya selama seminggu (S5T4, S5T5).

2) Kesalahan menginterpretasi bahasa

Berdasarkan lembar jawaban subjek pada gambar 5 dan wawancara terlihat bahwa terlihat bahwa subjek keliru dalam menafsirkan pilihan kedua andre yaitu subjek menganggap gaji andre sebesar 10.000/hari padahal gaji andre sebesar 10.000 pada hari pertama dan bertambah 2 kali lipat tiap harinya (S5T4).

3) Kesalahan menggunakan logika untuk menarik kesimpulan

Berdasarkan lembar jawaban subjek pada gambar 5 dan wawancara terlihat bahwa subjek keliru dalam mengambil kesimpulan dengan menentukan bahwa ketika andre di beri gaji Rp 10.000 pada hari pertama dan bertambah dua kali lipat tiap harinya selama seminggu subjek langsung menarik kesimpulan bahwa gaji andre hanya 10.000/hari sehingga subjek menarik kesimpulan bahwa soal tersebut diselesaikan dengan cara mengalikan nilai a dengan $\mathrm{n}$ padahal soal tersebut adalah deret geometri (S5T4, S5T5).

4) Kesalahan menggunakan definisi atau teorema

Berdasarkan lembar jawaban subjek pada gambar 5 dan wawancara terlihat bahwa terlihat subjek telah menuliskan rumus yang dibutuhkan dalam menyelesaikan soal yaitu $\mathrm{Sn}=\mathrm{a} \times \mathrm{n}$ Tetapi subjek keliru dalam menentukan rumus yang digunakan untuk pilihan kedua. Rumus yang 
dibutuhkan untuk penyelesaian soal tersebut adalah deret geometri yaitu $S_{n}=\frac{a\left(r^{n}-1\right)}{r-1}(\mathrm{~S} 5 \mathrm{~T} 5)$.

ii. Soal nomor 3

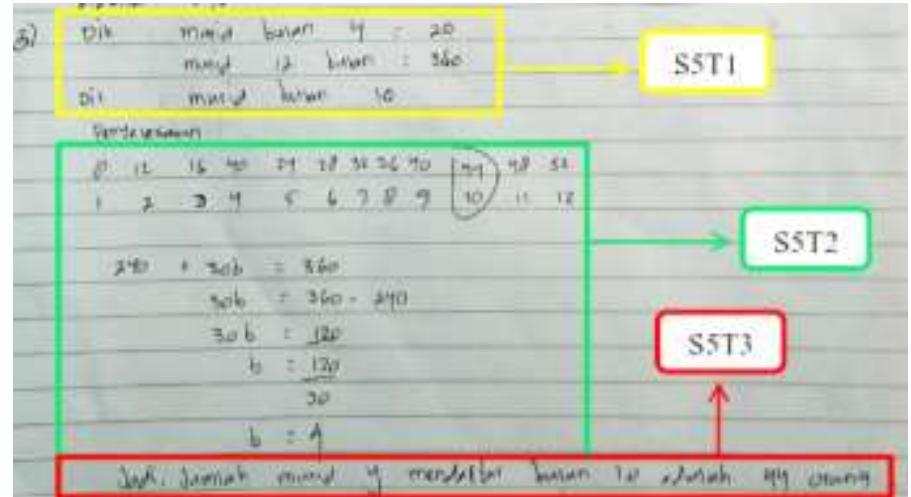

Gambar 6. Jawaban subjek 2 soal nomor 3

Berdasarkan lembar jawaban subjek pada gambar 6 dan wawancara terlihat bahwa subjek menuliskan langkah penyelesaian yang tidak lengkap, terlihat subjek menuliskan suatu persamaan yaitu $240+30 \mathrm{~b}=360$ tetapi tidak menuliskan langkah penyelesaian untuk mendapatkan persamaan tersebut (S5T2).

iii. Soal nomor 4

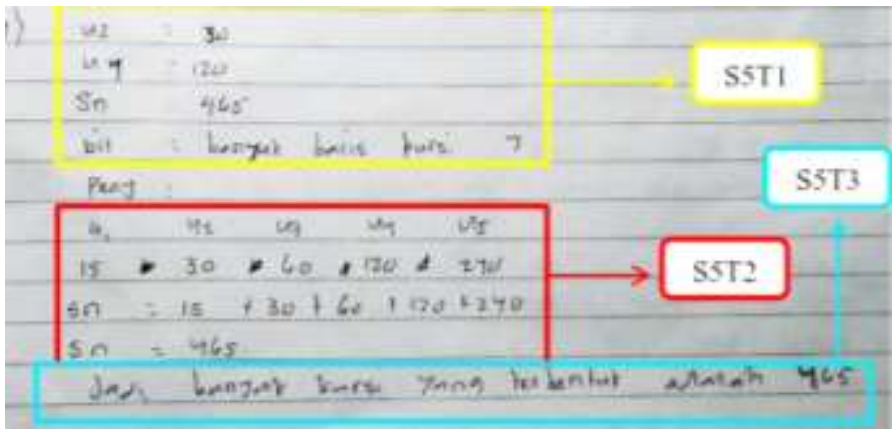

Gambar 7. Jawaban subjek 2 soal nomor 4

Berdasarkan lembar jawaban subjek pada gambar 7 dan wawancara terlihat bahwa jawaban akhir subjek tidak sesuai dengan langkah penyelesaiannya. Subjek menuliskan jawaban akhirnya yaitu banyak kursi yang terbentuk adalah 465 kursi padahal yang ditanyakan pada soal adalah berapa banyak baris kursi. Dan dari hasil pekerjaan subjek terlihat bahwa subjek telah mendapatkan banyak baris kursi yaitu 5 baris tetapi jawaban akhirnya salah karena subjek menuliskan jumlah kursi yaitu 465 (S5T2, S5T3).

\subsection{Pembahasan}

Berdasarkan data yang diperoleh, terlihat bahwa jenis kesalahan yang dilakukan siswa kelas VIII SMP Satap 3 Tellu Limpoe Kabupaten Bone dalam menyelesaikan soal matematika berbasis HOTS pada materi pola bilangan berdasarkan kriteria Hadar sebagai berikut:

a. Subjek 1

1) Kesalahan menggunakan data 
Menurut (Kusmaryono \& Java, 2018) kesalahan yang tercakup dalam kesalahan data yaitu tidak menuliskan informasi dari soal secara lengkap, kurang tepatnya siswa menyalin data dari soal, siswa menambahkan data-data yang tidak sesuai, mengabaikan data yang diberikan, menyatakan suatu syarat yang tidak dibutuhkan, mengartikan informasi tidak sesuai dengan teks sebenarnya.

Berdasarkan data hasil analisis tes tertulis dan wawancara, dapat dipaparkan bahwa subjek melakukan kesalahan menggunakan data dalam menyelesaikan soal nomor 1 dan 2 . Pada soal nomor 1 , kesalahan menggunakan data yang terjadi yaitu subjek mengartikan informasi pada soal tidak sesuai dengan teks sebenarnya sehingga subjek mengabaikan sebagian data dalam menyelesaikan soal yaitu subjek mengabaikan data jika jumlah bakteri membelah diri menjadi tiga setiap 13 menit, dan subjek tidak mencari waktu t yang dibutuhkan sehingga jumlah bakteri menjadi 14.580 ketika membelah diri menjadi 3 setiap 13 menit sebelum menentukan jumlah bakteri jika membelah diri menjadi 3 setiap 26 menit setelah waktu t. Data yang digunakan dalam menyelesaikan soal nomor 1 hanya jumlah bakteri mula-mula dan ketika bakteri membelah diri menjadi tiga setiap 26 menit. Pada soal nomor 2, subjek sebenarnya dapat menyebutkan informasi apa yang diketahui dan ditanyakan pada soal tetapi subjek mengartikan infomasi pada soal tidak sesuai dengan teks sebenarnya yaitu subjek menganggap bahwa pada gaji yang diberikan pada pilihan kedua andre yaitu Rp10.000 pada hari pertama dan hanya akan bertambah 2 setiap harinya padahal informasi pada soal gaji andre akan bertambah 2 kali lipat tiap harinya selama seminggu.

Pada jenis kesalahan ini subjek subjek mengabaikan sebagian data yang diberikan dan subjek mengartikan informasi soal tidak sesuai dengan teks sebenarnya. Hal ini sejalan dengan penelitian yang mengungkapkan bahwa kesalahan menggunakan data yaitu mengabaikan data penting yang diberikan, mengartikan informasi tidak sesuai dengan teks sebenarnya dan kesalahan menyalin data (Wahyuningsih et al., 2020,Putri, 2018).

2) Kesalahan menginterpretasi bahasa

Menurut (Laman, 2019, Kusmaryono \& Java, 2018) karakteristik yang meliputi kesalahan menginterpretasi bahasa yaitu kesalahan siswa mengubah bahasa sehari-hari kedalam bentuk persamaan matematika dengan arti yang berbeda, menulis simbol dari suatu konsep dengan simbol lain yang artinya berbeda, dan salah mengartikan grafik.

Berdasarkan data hasil analisis tes tertulis dan wawancara, dapat dipaparkan bahwa subjek melakukan kesalahan menginterpretasi bahasa dalam menyelesaikan soal nomor 1, 2 dan 3. Pada soal nomor 1, terlihat subjek keliru dalam menafsirkan diperlukan waktu t agar jumlah bakteri menjadi 14.580, subjek manganggap bahwa waktunya itu adalah ketika bakteri membelah diri menjadi 3 setiap 13 menit. Sehingga subjek menganggap yang ditanyakan pada soal yaitu 
banyak bakteri ketika membelah diri menjadi 3 setiap 26 menit padahal yang ditanyakan adalah banyak bakteri ketika membelah diri menjadi 3 setiap 26 menit setelah waktu t.

Pada soal nomor 2, terlihat di pilihan kedua gaji andre sebesar 10.000 pada hari pertama dan bertambah 2 kali lipat tiap harinya subjek menganggap bahwa gajinya hanya bertambah 2 setiap harinya yaitu $10.000+2$ dan seterusnya, padahal sebenarnya gaji andre bertambah 2 kali lipat tiap harinya yaitu $10.000 \mathrm{x} 2$ dan seterusnya sehingga subjek salah dalam membuat model matematikanya yaitu $b=$ 2 padahal yang diketahui pada soal adalah $\mathrm{r}=2$.

Pada soal nomor 3, subjek keliru dalam menafsirkan informasi pada soal yaitu jumlah murid yang mendaftar pada bulan ke 4 ada 20 murid dimana subjek menganggap pendaftaran dimulai bulan 4 sehingga subjek menentukan bahwa suku pertamanya adalah 20 padahal bulan ke empat merupakan $\mathrm{U}_{4}$.

Pada jenis kesalahan ini subjek tidak memahami makna soal sehingga subjek mengubah soal cerita ke dalam bentuk model matematika dengan arti yang berbeda. Hal ini sejalan dengan penelitian (Putri, 2018) mengungkapkan bahwa kesalahan menginterpretasi bahasa di mana subjek salah dalam memahami kalimat soal dan subjek kurang mampu mengubah informasi yang diketahui dari soal kedalam model matematika dengan benar.

3) Kesalahan menggunakan logika untuk menarik kesimpulan

Menurut Hadar, dkk (Laman, 2019) kesalahan menggunakan logika untuk menarik kesimpulan ialah kesalahan yang biasa dilakukan siswa pada saat menarik kesimpulan dari suatu masalah yang diberikan. Berdasarkan data hasil analisis tes tertulis dan wawancara, dapat dipaparkan bahwa subjek melakukan kesalahan menggunakan logika untuk menarik kesimpulan dalam menyelesaikan soal nomor 1,2 dan 3.

Pada soal nomor 1, subjek keliru dalam mengambil kesimpulan dengan menentukan bahwa ketika jumlah bakteri menjadi 14.580 waktunya hanya 13 menit, dan keliru menentukan bahwa yang ditanyakan adalah jumlah bakteri ketika membelah diri menjadi 3 setiap 26 menit setelah waktu t karena subjek menganggap yang ditanyakan adalah jumlah bakteri ketika membelah diri menjadi 3 dalam waktu 26 menit, sebaiknya subjek harus menentukan berapa waktu yang di butuhkan sehingga jumlah bakteri menjadi 14.580 ketika membelah diri menjadi 3 setiap 13 menit sebelum menentukan jumlah bakteri setelah waktu t ketika membelah diri menjadi 3 setiap 26 menit.

Pada soal nomor 2, subjek keliru dalam mengambil kesimpulan dengan menentukan bahwa ketika andre di beri gaji $\mathrm{Rp} 10.000$ pada hari pertama dan bertambah dua kali lipat tiap harinya selama seminggu subjek langsung menarik 
kesimpulan bahwa gaji andre hanya akan bertambah 2 tiap harinya selama seminggu sehingga subjek menarik kesimpulan bahwa soal tersebut merupakan deret aritmatika padahal soal tersebut adalah deret geometri.

Pada soal nomor 3, subjek keliru dalam mengambil kesimpulan bahwa pendaftaran murid baru di mulai bulan 4 sehingga subjek menentukan suku pertamanya yaitu 20 bahwa subjek keliru dalam mengambil kesimpulan bahwa pendaftaran murid baru di mulai bulan 4 sehingga subjek menentukan suku pertamanya yaitu 20 seharusnya subjek mencari jumlah murid yang mendaftar pada bulan 1, 2 dan 3 yaitu $\mathrm{U}_{1}, \mathrm{U}_{2}$, dan $\mathrm{U}_{3}$ sebelum menentukan jumlah murid yang mendaftar bulan 10 karena jumlah murid baru yang mendaftar selama 1 tahun pertama adalah 360 orang berarti pendaftaran murid baru mulai dari bulan 1 sampai bulan 12 .

Pada jenis kesalahan ini subjek mengambil kesimpulan kurang tepat dalam menentukan bagaimana langkah awal untuk menyelesaikan masalah pada soal. Hal ini sejalan dengan penelitian (Wahyuningsih et al., 2020) mengungkapkan bahwa kesalahan menggunakan logika untuk menarik kesimpulan di mana siswa mengambil kesimpulan yang kurang tepat untuk menyelesaikan soal.

4) Kesalahan menggunakan definisi atau teorema

Menurut Hadar, dkk (Laman, 2019) kesalahan ini biasa dilakukan siswa pada saat menyelesaiakan permasalahan yang dituntut menggunakan rumus, teorema, prinsip, ataupun defenisi matematika. Contohnya menerapkan suatu teorema pada kondisi yang tidak sesuai, dan tidak teliti atau tidak tepat dalam mengutip definisi, rumus, atau teorema.

Berdasarkan data hasil analisis tes tertulis dan wawancara, dapat dipaparkan bahwa subjek melakukan kesalahan menggunakan definisi atau teorema dalam menyelesaikan soal nomor 1 dan 2. Pada soal nomor 1, subjek mampu menyebutkan konsep yang digunakan pada soal yaitu konsep barisan geometri tetapi subjek keliru menuliskan rumus barisan geometri yaitu $U_{n}=a x r^{t}$, sedangkan rumus barisan geometri yang tepat adalah $U_{n}=a r^{n-1}$.

Pada soal nomor 2, subjek menyebutkan konsep yang digunakan pada pilihan pertama yaitu a $\mathrm{x} n$ pilihan kedua yaitu rumus deret aritmatika $S_{n}=\frac{n}{2}(2 a+$ $(n-1) b)$ tetapi subjek keliru dalam menetukan rumus yang harus digunakan pilihan kedua seharusnya subjek menggunakan rumus deret geometri $S_{n}=\frac{a\left(r^{n}-1\right)}{r-1}$ . Subjek keliru dalam menentukan rumus yang tepat untuk menyelesaikan soal nomor 2 karena subjek menganggap gaji andre hanya bertambah 2 setiap harinya sehingga subjek menggunakan rumus deret aritmatika.

Pada jenis kesalahan ini subjek menerapkan rumus pada kondisi yang tidak sesuai, dan tidak teliti atau tidak tepat dalam menerapkan rumus untuk menyelesaikan 
soal. Hal ini sejalan dengan penelitian (Wahyuningsih et al., 2020)mengungkapkan bahwa kesalahan menggunakan definisi atau teorema di mana subjek melakukan kesalahan dalam menerapkan rumus untuk menyelesaikan soal.

5) Penyelesaian tidak diperiksa kembali

Menurut Hadar, dkk (Laman, 2019) jenis kesalahan ini terjadi jika setiap langkah penyelesaian yang dilakukan oleh siswa tidak sesuai dengan hasil akhir. Jenis kesalahan ini terjadi ketika siswa mengerjakan soal secara terburu-buru sehingga pekerjaannya tidak dikoreksi kembali. Berdasarkan data hasil analisis tes tertulis dan wawancara, dapat dipaparkan bahwa subjek melakukan kesalahan karena penyelesaian tidak diperiksa kembali dalam menyelesaikan soal nomor 2 dan 4 .

Pada soal nomor 2, subjek tidak memeriksa ulang kembali jawabannya sehingga subjek lupa menuliskan kesimpulan dari jawabannya sehingga subjek tidak menjawab apa yang ditanyakan dari soal. Sedangkan, pada soal nomor 4, subjek tidak memeriksa ulang kembali jawabannya sehingga hasil akhir dan langkah penyelesaian subjek berbeda yaitu subjek menuliskan jumlah baris kursi adalah 6 baris padahal di langkah penyelesaiannya subjek telah mendapatkan banyak barisan kursi adalah 5 baris karena subjek mengerjakan soal sacara terburu-buru.

Pada jenis kesalahan ini subjek tidak menuliskan jawaban akhirnya, dan jawaban subjek dan langkah penyelesaiannya berbeda karena subjek mengerjakan soal secara terburu-buru. Dan sejalan dengan penelitian (Wahyuningsih et al., 2020,Putri, 2018) mengungkapkan bahwa terjadi kesalahan karena penyelesaian tidak diperiksa kembali di mana subjek salah dalam menuliskan hasil akhir.

b. Subjek 2

1) Kesalahan menggunakan data

Menurut Hadar, dkk (Laman, 2019) kesalahan yang tercakup dalam kesalahan data yaitu tidak menuliskan informasi dari soal secara lengkap, kurang tepatnya siswa menyalin data dari soal, siswa menambahkan data-data yang tidak sesuai, mengabaikan data yang diberikan, menyatakan suatu syarat yang tidak dibutuhkan, mengartikan informasi tidak sesuai dengan teks sebenarnya.

Berdasarkan data hasil analisis tes tertulis dan wawancara, dapat dipaparkan bahwa subjek melakukan kesalahan menggunakan data dalam menyelesaikan soal nomor 2. Kesalahan menggunakan data yang terjadi yaitu subjek mengabaikan sebagian data dalam menyelesaikan soal yaitu subjek mengabaikan data gaji andre bertambah 2 kali lipat tiap harinya sehingga sehingga subjek melakukan kesalahan menggunakan data.

Pada jenis kesalahan ini subjek subjek mengabaikan sebagian data yang diberikan. Hal ini sejalan dengan penelitian (Wahyuningsih et al., 2020) yang mengungkapkan bahwa kesalahan menggunakan data yaitu mengabaikan data penting yang 
diberikan, mengartikan informasi tidak sesuai dengan teks sebenarnya dan kesalahan menyalin data.

2) Kesalahan menginterpretasi bahasa

Menurut Hadar, dkk (Laman, 2019) karakteristik yang meliputi kesalahan menginterpretasi bahasa yaitu kesalahan siswa mengubah bahasa sehari-hari kedalam bentuk persamaan matematika dengan arti yang berbeda, menulis simbol dari suatu konsep dengan simbol lain yang artinya berbeda, dan salah mengartikan grafik.

Berdasarkan data hasil analisis tes tertulis dan wawancara, dapat dipaparkan bahwa subjek melakukan kesalahan menginterpretasi bahasa dalam menyelesaikan soal nomor 2. subjek keliru dalam menafsirkan pilihan kedua andre yaitu subjek menganggap gaji andre sebesar 10.000/hari padahal gaji andre sebesar 10.000 pada hari pertama dan bertambah 2 kali lipat tiap harinya.

Pada jenis kesalahan ini subjek tidak memahami makna soal sehingga subjek mengubah soal cerita ke dalam bentuk model matematika dengan arti yang berbeda. Hal ini sejalan dengan penelitian (Wahyuningsih et al., 2020) mengungkapkan bahwa kesalahan menginterpretasi bahasa di mana subjek salah dalam memahami kalimat soal dan subjek kurang mampu mengubah informasi yang diketahui dari soal kedalam model matematika dengan benar.

3) Kesalahan menggunakan logika untuk menarik kesimpulan

Menurut Hadar, dkk (Laman, 2019) kesalahan menggunakan logika untuk menarik kesimpulan ialah kesalahan yang biasa dilakukan siswa pada saat menarik kesimpulan dari suatu masalah yang diberikan.

Berdasarkan data hasil analisis tes tertulis dan wawancara, dapat dipaparkan bahwa subjek melakukan kesalahan menggunakan logika untuk menarik kesimpulan dalam menyelesaikan soal nomor 2. subjek keliru dalam mengambil kesimpulan di pilihan kedua dengan menentukan bahwa ketika andre di beri gaji Rp 10.000 pada hari pertama dan bertambah dua kali lipat tiap harinya selama seminggu subjek langsung menarik kesimpulan bahwa gaji andre 10.000/hari selama seminggu sehingga subjek menarik kesimpulan bahwa soal tersebut di selesaikan dengan langsung mengalikan nilai a dan $\mathrm{n}$ padahal soal tersebut adalah deret geometri.

Pada jenis kesalahan ini subjek mengambil kesimpulan kurang tepat dalam menentukan bagaimana langkah awal untuk menyelesaikan masalah pada soal. Hal ini sejalan dengan peneitian (Wahyuningsih et al., 2020) mengungkapkan bahwa kesalahan menggunakan logika untuk menarik kesimpulan di mana siswa mengambil kesimpulan yang kurang tepat untuk menyelesaikan soal. 
4) Kesalahan menggunakan definisi atau teorema

Menurut Hadar, dkk (Laman, 2019) kesalahan ini biasa dilakukan siswa pada saat menyelesaiakan permasalahan yang dituntut menggunakan rumus, teorema, prinsip, ataupun defenisi matematika. Contohnya menerapkan suatu teorema pada kondisi yang tidak sesuai, dan tidak teliti atau tidak tepat dalam mengutip definisi, rumus, atau teorema.

Berdasarkan data hasil analisis tes tertulis dan wawancara, dapat dipaparkan bahwa subjek melakukan kesalahan menggunakan definisi atau teorema dalam menyelesaikan soal nomor 2. Subjek telah menuliskan konsep yang digunakan untuk menyelesaikan soal yaitu a $\mathrm{x} n$ tetapi subjek keliru dalam menetukan rumus yang harus digunakan pilihan kedua seharusnya subjek menggunakan rumus deret geometri $S_{n}=\frac{a\left(r^{n}-1\right)}{r-1}$. Subjek keliru dalam menentukan rumus yang tepat untuk menyelesaikan pilihan kedua pada soal nomor 2 karena subjek menganggap gaji andre hanya 10.000/hari padahal gaji sebesar 10.000 merupakan gaji andre di hari pertama.

Pada jenis kesalahan ini subjek menerapkan rumus pada kondisi yang tidak sesuai. Hal ini sejalan dengan penelitian (Wahyuningsih et al., 2020,Putri, 2018) mengungkapkan bahwa kesalahan menggunakan definisi atau teorema di mana subjek melakukan kesalahan dalam menerapkan rumus untuk menyelesaikan soal.

5) Penyelesaian tidak diperiksa kembali

Menurut Hadar, dkk (Laman, 2019) jenis kesalahan ini terjadi jika setiap langkah penyelesaian yang dilakukan oleh siswa tidak sesuai dengan hasil akhir. Jenis kesalahan ini terjadi ketika siswa mengerjakan soal secara terburu-buru sehingga pekerjaannya tidak dikoreksi kembali.

Berdasarkan data hasil analisis tes tertulis dan wawancara, dapat dipaparkan bahwa subjek melakukan kesalahan karena penyelesaian tidak diperiksa kembali dalam menyelesaikan soal nomor 3 dan 4. Pada soal nomor 3 , subjek tidak menuliskan langkah penyelesaiannya secara lengkap yaitu subjek tidak menuliskan langkah penyelesaian untuk mendapatkan persamaan $240+30 \mathrm{~b}=360$ karena subjek mengerjakan soal secara terburu-buru.

Pada soal nomor 4, subjek tidak memeriksa ulang kembali jawabannya sehingga hasil akhir dan langkah penyelesaian subjek berbeda yaitu subjek menuliskan jumlah baris kursi adalah 465 padahal di langkah penyelesaiannya subjek telah mendapatkan banyak barisan kursi adalah 5 baris karena subjek mengerjakan soal sacara terburu-buru.

Pada jenis kesalahan ini subjek tidak menuliskan langkah penyelesaiannya secara lengkap, dan jawaban subjek dan langkah penyelesaiannya berbeda karena subjek 
mengerjakan soal secara terburu-buru. Hal ini sejalan dengan penelitian (Wahyuningsih et al., 2020) mengungkapkan bahwa penyelesaian tidak diperiksa kembali di mana subjek melakukan kesalahan dengan tidak memeriksa ulang penyelesaiannya. Dan sejalan dengan penelitian (Putri, 2018) mengungkapkan bahwa terjadi kesalahan karena penyelesaian tidak diperiksa kembali di mana subjek salah dalam menuliskan hasil akhir.

\section{SIMPULAN}

Setelah penelitian dilakukan, dapat di simpulkan bahwa jenis kesalahan yang dilakukan siswa dalam menyelesaikan soal matematika berbasis HOTS pada materi pola bilangan berdasarkan kriteria Hadar adalah antara lain:

a. Kesalahan menggunakan data

Siswa mengabaikan sebagian data yang diberikan dan informasi pada soal yang diartikan oleh siswa tidak sama dengan kalimat sebetulnya.

b. Kesalahan menginterpretasi bahasa

Siswa kurang tahu apa mau soal, hingga kalimat dalam soal diubah ke persamaan matematika dengan makna yang beda.

c. Kesalahan menggunakan logika ketika menarik kesimpulan

Siswa mengambil kesimpulan kurang tepat dalam menentukan bagaimana langkah awal dalam menyelesaikan masalah pada soal.

d. Kesalahan menggunakan definisi ataupun teorema

Siswa menerapkan rumus dalam kondisi yang kurang tepat, dan kurang teliti ketika menerapkan rumus untuk menyelesaikan soal.

e. Penyelesaiannya tidak diperiksa kembali

Siswa tidak menulis kesimpulan dari jawabannya, serta jawaban siswa dan langkah penyelesaiannya berbeda karena siswa mengerjakan soal secara terburu-buru.

\section{REKOMENDASI}

Dari kesimpulan yang didapatkan peneliti ingin mengajukan saran sebagai berikut:

a. Terlihat masih banyak siswa tidak bisa mengerjakan soal matematika berbasis HOTS. Oleh sebab itu diharapkan guru dapat memberikan lebih banyak latihan-latihan terkait dengan soal matematika berbasis HOTS dalam setiap proses pembelajaran.

b. Berdasarkan jenis kesalahan yang dilakukan siswa maka hendaknya guru meminimalisir kesalahan tersebut, dengan jenis-jenis kesalahan sebagai berikut.

i. kesalahan menggunakan data, kemungkinan cara untuk mengatasi kesalahan tersebut yaitu guru meminta siswa agar membaca dan memahami informasi apa yang ada pada soal sehingga tidak terjadi kesalahan dalam menggunakan data.

ii. Kesalahan menginterpretasi bahasa, kemungkinan cara yang dapat mengatasi kesalahan tersebut adalah guru memberikan banyak latihan soal cerita.

iii. Kesalahan menggunakan logika untuk menarik kesimpulan, kemungkinan cara untuk mengatasi kesalahan ini adalah guru memberikan pertanyaan arahan yang dapat menuntun siswa menentukan langkah untuk menyelesaikan soal. 
iv. Kesalahan menggunakan definisi atau teorema, kemungkinan yang dapat mengatasi kesalahan tersebut adalah guru di minta menjelaskan materi dengan baik pada soal sehingga siswa mengetahui rumus yang tepat ketika mengerjakan soal yang di berikan serta siswa di harapkan memahami materi yang terkait dengan soal.

v. Kesalahan yang terjadi karena penyelesaian tidak di periksa kembali, kemungkinan cara yang bisa mengatasi kesalahan tersebut yaitu guru diminta mengingatkan siswa untuk memeriksa kembali setiap langkah penyelesaiannya sebelum di kumpulkan.

\section{REFERENSI}

Amalia, A., \& Pujiastuti, H. (2020). Analisis kemampuan berpikir tingkat tinggi pada siswa smp ypwks cilegon dalam menyelesaikan soal pola bilangan. Wahana Didaktika, 1(8), 247-254.

Anwar, Z., \& Hidayani. (2020). Analisis kesalahan siswa smp kelas viii dalam menyelesaikan soal lingkaran. Mercumatika: Jurnal Penelitian Matematika dan Pendidikan Matematika, 4(2), $71-79$.

Gina, M., Jusniani, N., \& Budiman, H. (2021). Mathematical representation ability of junior high school students on surface area of cube and cuboid. Prima Jurnal Pendidian Matematika, $5(1), 72-82$.

Gusman, R. N., Suryani, M., \& Jufri, L. H. (2021). Matematika berdasarkan kriteria hadar analysis of student errors in completing the problems of understanding the concept of mathematics based on the criteria of hadars from student's early abilities. Jurnal Equation,Teori Dan Penelitian Pendidikan Matematika, 4(2), 19-28.

Kepa, S., \& Ramli, H. (2021). Analysis of errors of eleventh science 1 national senior high school 1 middle maluku in resolving trigonometry function limit problems and remediation efforts. Erudio Journal of Education Innovation, 8(1), 61-72.

Kusmaryono, I., \& Java, C. (2018). Analysis of students ' incorrect answers in a mathematical test: an insight on students ' learning. Jurnal Pengajaran MIPA (Journal of Mathematics and Science Teaching), 23(1), 1-8. https://doi.org/10.18269/jpmipa.v23i1.9517

Kusnadi, D., Tahmir, S., \& Minggi, I. (2014). Implementasi kurikulum 2013 dalam pembelajaran matematika di sma negeri 1 makassar. Mapan, 2(1), 123-135.

Laman, E. G. (2019). Analisis kesalahan siswa dalam memecahkan masalah matematika higher order thinking skills (hots) berdasarkan kriteria hadar ditinjau dari kemampuan awal siswa kelas xii sman 5 makassar. Universitas Negeri Makassar.

Manik, P., Saraswati, S., Ngurah, G., \& Agustika, S. (2020). Kemampuan berpikir tingkat tinggi dalam menyelesaikan soal hots mata pelajaran matematika. 4(2), 257-269.

Purbaningrum, K. A. (2017). Kemampuan berpikir tingkat tinggi siswa smp dalam pemecahan masalah matematika ditinjau dari gaya belajar. Jurnal Penelitian Dan Pembelajaran Matematika, 10(2), 40-49. https://doi.org/10.30870/jppm.v10i2.2029

Putri, Y. A. (2018). Analisis kesalahan siswa kelas viii smp negeri 19 mataram dalam menyelesaikan soal-soal materi pokok lingkaran tahun pelajaran 2017/2018. Universitas Mataram. 
Rasyidi, D. A., \& Winarso, W. (2020). The Proportion of Cognitive Aspects of Question in Mathematics Textbook Based on Marzano's Taxonomy: An Indonesian Case in Implementing New Curriculum. Eduma Mathematics Education Learning and Teaching, 9(2), 79-89.

Ratumanan, T. G., \& Tetelepta, Y. (2019). Analisis pembelajaran matematika berdasarkan kurikulum 2013 pada sma negeri 1 masohi analysis of mathematical learning based on 2013 curriculum at sma negeri 1 masohi. Jumadika Jurnal Magister Pendidikan Matematika, 1(1), $25-34$.

Schnepper, L. C., Mccoy, L. P., Schnepper, L. C., \& Mccoy, L. P. (2014). Analysis of Misconceptions in High School Mathematics Analysis of Misconceptions in High School Mathematics. Journal for Teacher Research, 15(1), 625-625. http://doi.org/10.4148/2470-6353.1066

Wahyuningsih, D. W. I., Sunan, U. I. N., Surabaya, A., Tarbiyah, F., Keguruan, D. A. N., Pendidikan, J., Dan, M., \& Matematika, P. P. (2020). Analisis kesalahan peserta didik dalam menyelesaikan soal higher order thinking skills un berdasarkan kriteria hadar. 